\title{
ACCUMULATION OF HEAVY METALS IN ORGANS OF AQUEOUS PLANTS AND ITS ASSOCIATION WITH BOTTOM SEDIMENTS IN BUG RIVER (POLAND)
}

\author{
Elżbieta Skorbiłowicz' ${ }^{1}$ Mirosław Skorbiłowicz' ${ }^{1}$ Dorota Malinowska' \\ 1 BialystokUniversity of Technology, Wiejska 45A Str., 15-351 Bialystok, Poland, e-mail:e.skorbilowicz@pb.edu.pl
}

Received: 2016.05 .16

Accepted: 2016.08.08 Published: 2016.09 .20

\begin{abstract}
The article presents the results of studies upon metals $(\mathrm{Pb}, \mathrm{Zn}, \mathrm{Cr}, \mathrm{Ni}, \mathrm{Cu}, \mathrm{Co})$ in bottom sediments and in various parts of the aquatic plants taken from the Bug river (Poland). The metal contents in the examined environmental elements were determined by AAS technique. The aim of this study was to evaluate the content of metals in bottom sediments and macrophytes (root, stem, leaf) occurring in the Bug river. It was hypothesized that the heavy metal content in plant tissues reflects the amount of metals in sediments. It has been shown that the average metal distribution in the examined plants present in the Bug river and bottom sediments was as follows: $\mathrm{Pb}, \mathrm{Zn}, \mathrm{Co}$, and $\mathrm{Cu}$ sediments $>\operatorname{root}>\operatorname{leaf}>$ stem, while in the case of $\mathrm{Ni}$ and $\mathrm{Cr}$, the contents were greater in roots than in sediment ( root $>$ sediment $>$ leaf $>$ stem), although the differences in contents were not large. The study showed that most metals are present in roots and only a small part of them is transported to the stem and leaves. The size of the metal movement within plants may depend on their contents. It was found that for $\mathrm{Ni}, \mathrm{Cr}$ and $\mathrm{Cu}$ in 2014, the bioaccumulation factor was above one, which confirms the high efficiency of metals uptake from the environment as evidenced by statistical analysis. Bioaccumulation factor (BF) was smaller than one for $\mathrm{Pb}, \mathrm{Co}$ and $\mathrm{Zn}$, confirming the high ability to retain metals in the root. Aquatic plants are an effective barrier for the surface water by accumulating heavy metals in their biomass. Macrophytes are proposed to monitor the river pollution.
\end{abstract}

Keywords: heavy metal, bottom sediments, aquatic plant, river.

\section{INTRODUCTION}

Heavy metals in surface water ecosystems come from both natural and anthropogenic sources. In view of the intense human activity, natural sources of heavy metals from leaching and weathering of rocks in the environment, are usually of little importance [Kabata Pendias and Pendias 1999]. Anthropogenic sources of heavy metals are associated with the disposal of wastewater from mining and of mineral resources processing [Helios-Rybicka et al. 2001, Karczewska 2002], industry [Dmochowski 1995], and cities [Dauvalter Rognerud, 2001, Skorbiłowicz and Bojakowska 2006], as well as common use of metals and their compounds in various types of economic activity, including agriculture [Mazur et al. 2002] and transport [Gworek, Kwasocki 2001]. Heavy metals present in the water, even in small concentrations, are very quickly accumulated in bottom sediments (Linnik and Zubenko 2000, Yang et al. 2008]. The content of trace elements in alluvia is therefore a good indicator of the natural environment state and its changes [Helios-Rybicka 1991]. An additional element of the heavy metals content assessment in rivers is their concentration in aquatic plants [Fediuc and Erdei 2002]. Many research works present issues concerning the impact of bottom sediments from rivers and lakes on emerged and submerged macrophytes [BarratSegretain 2001, Mazej Germ 2009, Fritioff and Greger 2006]. The accumulation of metals in 
plants is a complex process that depends on the vegetation species, type of element, and a number of biotic and abiotic factors [Otte i Jakuba 2005, Sousa et al. 2008].

The aim of the study was to assess the content of metals ( $\mathrm{Pb}, \mathrm{Zn}, \mathrm{Cr}, \mathrm{Ni}, \mathrm{Cu}, \mathrm{Co})$ in bottom sediments and macrophytes found in the Bug river. It was hypothesized that the heavy metal content in plant tissues reflects their amount in sediments.

\section{METHODS}

\section{Area of study}

The Bug river catchment is located in an area of north-west Ukraine, south-western Belarus, and central-eastern Poland. Of the total catchment area, $19,400 \mathrm{~km}^{2}(49.24 \%)$ is located on Polish, $10,800 \mathrm{~km}^{2}(27.41 \%)$ on Ukrainian, and $9200 \mathrm{~km}^{2}(23.35 \%)$ on Belarusian territory. Bug flows into the Narew, which is the tributary of the Vistula river, near Zalew Zegrzyński. The entire length of the Bug river (from sources in Ukraine to Zalew Zegrzyński) is $755 \mathrm{~km}$, including almost $185 \mathrm{~km}$ that lies in the Ukraine.

The area of the Bug river is characterized by the following types of soil: sandy soil of different genetic types, such as podzolic, rusty, brown acidic, that lie in the highest parts of the plateau; pseudo-podzolic soil and specific brown soils, which remain in the lower parts of the plateau; marshy chernozem present in valley forms; alluvial soils, that are located in the river valley; peat and muck-mineral soils that are formed at the bottom of the valley forms and in marshy and declined areas.

The climate of the Bug river catchment is shaped by continental and marine air masses. The average annual temperature of the Bug river catchment maintains at about $7.0^{\circ} \mathrm{C}$. The wide spatial variation is displayed by rainfall in the catchment of the Bug river. In the area of Polesie, there are the lowest rainfall, which amounts to $530-550 \mathrm{~mm}$, while in Roztocze, the highest amounting to above $650 \mathrm{~mm}$ per year.

The Bug river has a winding riverbed with many oxbow lakes, islands and bays. It is distinguished by the diversity of plant communities occurring due to natural and anthropogenic (agriculture) factors. There are numerous processes of erosion and accumulation, causing the formation and differentiation of habitats within the riverbeds and river embankments. Distribution of plant and animal organisms largely depends on the flooding of the river, the amount and composition of the material carried in, and the level of groundwater. Riverbeds, embankments, valleys, channels, and oxbow lakes include numerous aquatic vegetation and rushes. It is diverse and depends on the size of a river section and its naturalness. In areas with slower water flow, there is a surface floating vegetation of Lemnetea minoris class. Yellow water-lily (Nuphar lutea) and pondweed communities (shining pondweed Potametum lucentris, curled pondweed Potametum crispus, and sago pondweed Potametum pectinati) are also numerous. Among the most common associations on embankments and riverbeds, there are: Sigittario-Sparganietum emersi with dominating arrowhead. The edges are covered with narrow strips of rushes, including Phalaridetum arundinaceae with the representative reed canary grass. There are also associations of common reed Phragmitetum Australis, narrowleaf cattail Typhetum augustifoliae, reed sweet-grass Glycerietum maximae, and water horsetail Equisetum fluviatile. The coastal vegetation includes sedge, of which the most prevalent consists of associations of upright sedge Caricetum elatae, acute sedge Caricetum gracilis, and lesser pond-sedge Caricetum acutiformis. The zone between water and land is grown by associations of common reed Thelypteridi-Phragmitetum, Equisetetum fluviatile with water horsetail, Iridetum pseudacori with water flag, Phalaridetum arundinaceae with reed canary grass, and Glycerietum maximae with red sweet-grass [Dombrowski et. al.]

A growing economy, and in particular the various industries, for many years has a negative impact on the environment, especially, it causes a great threat to the existence of natural ecosystems in surface waters. Bug river along with its tributaries are the receivers of wastewater from industrial and municipal sources. The main point sources include sewage, which reach from the most populated cities (Siedlce, Biała Podlaska, Chełm, Siemiatycze, Włodawa, Terespol, Luków, Międzyrzec Podlaski), that is transported through the sewerage systems from urban and rural agglomerations. On the analyzed area, there are the glass, wood, furniture, food, tanning, clothing, leather, and cement industries. Mainly agri-food processing prevail, i.e. dairy cooperatives, sugar refineries, breweries, and factories processing fruits, vegetables and meat. The polluting factors 
are also wastewaters coming from the Ukraine. There are also the area pollution in the catchment arising as a result of leaching compounds from large areas. They are moved primarily by water flowing on the surface from agriculture, industry, traffic, households and dumps, and landfills.

\section{Field and laboratory works}

The field work was conducted in 2014 and 2015 at 10 measurement points located on the Bug river (Drohiczyn, Siemiatycze, Mielnik, Niemirów, Krzyczew, Terespol, Sławatycze, Włodawa, Dorohusk, and Horodło). The objects for analysis consisted of bottom sediments and aquatic plants (root, stem, leaf), in which contents of lead, zinc, cobalt, copper, chromium and nickel were determined. Several individual surface samples of bottom sediments (at a depth of $5 \mathrm{~cm}$ ) were collected from the water at any selected point. After mixing the research material, a representative sample was provided (the weight of about $1000 \mathrm{~g}$ ). The samples were then dried in air to the "air-dry" state and stored until testing [Lis and Pasieczna 1995]. Prior to chemical analyses, the bottom sediment sample was dried at $40{ }^{\circ} \mathrm{C}$ and sieved through a nylon mesh of 0.2 $\mathrm{mm}$. Bottom sediments were digested in nitric acid in closed microwave system CEM Mar-5. Concentrations of $\mathrm{Pb}, \mathrm{Co}, \mathrm{Cu}, \mathrm{Cr}, \mathrm{Zn}$, and $\mathrm{Ni}$ in bottom sediments were determined by means of AAS technique. Measurements were carried out using spectrometer Varian Spectra AA100. The correctness of the method was verified applying reference material NCSDC 733.

Plant material was collected from the same locations as bottom sediments (Table 1). Each plant test sample was formed by merging at least 10 individual samples. Upon arrival at the labo- ratory, harvested plants were washed thoroughly with tap water to remove sediments and periphytone and rinsed with distilled water. Then, plants were divided into roots, stems and leaves, and dried to a constant weight at $80{ }^{\circ} \mathrm{C}$ (Mazej and Germ, 2009). After drying, samples were subject to homogenization and digestion in microwave system CEM Mars-5 according to CEM method in mixture of $\mathrm{H}_{2} \mathrm{O}_{2}$ and $\mathrm{HNO}_{3}$ at high temperature and pressure. Contents of heavy metals $\mathrm{Pb}, \mathrm{Zn}$, $\mathrm{Cr}, \mathrm{Ni}, \mathrm{Cu}, \mathrm{Co}$ were determined by means of AAS technique applying Varian spectrometer. The measurement error was determined by comparing the results of determinations with the characteristics of two plant (mixture of herbs, tea leaves) certified reference materials: INCT-MPH-2 and INCT-TL-1. The calculated measurement error did not exceed $5 \%$ of the certified value. The achieved results of the studied metals content in bottom sediments and aquatic plants are given in relation to air-dry sediments.

For the statistical analysis of test results, Statistica 12 software was used. Values of arithmetic mean, standard deviation, and Pearson's correlation coefficients were calculated. The results were also analyzed by Ward agglomerative hierarchical clustering procedure (1993), based on the concept of the distance of objects or variables in a multidimensional space.

\section{RESULTS AND DISCUSSION}

Tables 2 and 3 show the results for metals in 2014 and 2015 in bottom sediments and parts of plants (root, stem, leaf). Bottom sediments play an important role in the functioning and circulation of elements in rivers. The average concentrations of metals were in the following order:

Table 1. Location of the measurement points and plant species on Bug river

\begin{tabular}{|l|l|}
\hline \multicolumn{1}{|c|}{ Measurement point } & \multicolumn{1}{c|}{ Species } \\
\hline Drohiczyn & alpine pondweed (Potamogeton alpinus Balb.) \\
\hline Siemiatycze & flowering rush (Butomus umbellatus L.) \\
\hline Mielnik & narrowleaf cattail (Typha angustifolia L.) \\
\hline Niemirów & least bur-reed (Sparganium minimum Fries) \\
\hline Krzyczew & reed sweet-grass (Glyceria maxima (Hartman) Holmb.) \\
\hline Terespol & floating sweet-grass (Glyceria fluitans (L.)R.Br.) \\
\hline Sławatycze & reed canary grass (Phalaris arundinacea L.) \\
\hline Włodawa & arrowhead (Sagittaria sagittifolia L. \\
\hline Dorohusk & sweet flag (Acorus calamus L.) \\
\hline Hordło & claspingleaf pondweed (Potamogeton perfoliatus L.) \\
\hline
\end{tabular}


Table 2. Contents of metals in bottom sediments of Bug river in 2014 and 2015 (mean \pm SD).

\begin{tabular}{|c|c|c|c|c|}
\hline \multicolumn{5}{|c|}{ Bottom sediments $\left[\mathrm{mg} \cdot \mathrm{kg}^{-1}\right] \mathrm{n}=10$} \\
\hline Metal & 2014 & 2015 & Geochemical background & Non-polluted sediments \\
\hline $\mathrm{Pb}$ & $21.8 \pm 10.55$ & $23.6 \pm 10.05$ & $15^{\mathrm{A}}, 20^{\mathrm{B}}$ & $30^{\mathrm{A}}, 30^{\mathrm{C}}$ \\
\hline $\mathrm{Zn}$ & $180.9 \pm 138.69$ & $168.6 \pm 129.29$ & $73^{\mathrm{A}}, 95^{\mathrm{B}}$ & $200^{\mathrm{A}}, 142^{\mathrm{C}}$ \\
\hline $\mathrm{Ni}$ & $6.8 \pm 2.10$ & $7.6 \pm 2.02$ & $5^{\mathrm{A}}, 68^{\mathrm{B}}$ & $16^{\mathrm{A}}, 102^{\mathrm{C}}$ \\
\hline $\mathrm{Co}$ & $4.6 \pm 1.28$ & $4.8 \pm 1.23$ & $3^{\mathrm{A}}, 19^{\mathrm{B}}$ & $28.5^{\mathrm{C}}$ \\
\hline $\mathrm{Cr}$ & $10.8 \pm 4.60$ & $11.6 \pm 4.31$ & $6^{\mathrm{A}}, 90^{\mathrm{B}}$ & $50^{\mathrm{A}}, 135^{\mathrm{C}}$ \\
\hline $\mathrm{Cu}$ & $5.5 \pm 3.35$ & $6.9 \pm 3.24$ & $7^{\mathrm{A}}, 45^{\mathrm{B}}$ & $40^{\mathrm{A}}, 67.5^{\mathrm{C}}$ \\
\hline
\end{tabular}

A - Bojakowska, Sokołowska (2001)

B - Turekian Wedepohl (1961)

C - Müller (1981)

Table 3. Contents of metals in aqueous plants (root, stem, leaf) in Bug river in 2014 and 2015 (mean \pm SD).

\begin{tabular}{|c|c|c|c|c|c|c|c|}
\hline \multicolumn{8}{|c|}{ Plants [mg $\left.\cdot \mathrm{kg}^{-1}\right] \mathrm{n}=10$} \\
\hline \multirow{2}{*}{ Metal } & \multicolumn{2}{|c|}{ root } & \multicolumn{2}{|c|}{ stem } & \multicolumn{2}{|c|}{ leaf } & \multirow{2}{*}{$\begin{array}{l}\text { Natural } \\
\text { content }\end{array}$} \\
\hline & 2014 & 2015 & 2014 & 2015 & 2014 & 2015 & \\
\hline $\mathrm{Pb}$ & $15.9 \pm 1.92$ & $20.3 \pm 7.66$ & $9.5 \pm 1.7$ & $13.5 \pm 3.39$ & $12.2 \pm 1.49$ & $12.3 \pm 2.48$ & $0.1-5^{\mathrm{B}}$ \\
\hline $\mathrm{Zn}$ & $69.2 \pm 36.21$ & $67.6 \pm 26.91$ & $31.6 \pm 9.07$ & $34.3 \pm 5.97$ & $39.4 \pm 15.92$ & $40.0 \pm 12.94$ & $10-70^{\mathrm{A}}$ \\
\hline $\mathrm{Ni}$ & $11.6 \pm 3.28$ & $8.1 \pm 1.98$ & $6.9 \pm 2.86$ & $6.4 \pm 1.82$ & $7.8 \pm 2.76$ & $6.4 \pm 1.80$ & $0.1-5^{\mathrm{A}}$ \\
\hline Co & $3.6 \pm 0.85$ & $3.3 \pm 0.61$ & $1.9 \pm 0.55$ & $2.2 \pm 0.65$ & $3.1 \pm 0.94$ & $4.3 \pm 2.40$ & $0.01-0.8^{\mathrm{A}}$ \\
\hline $\mathrm{Cr}$ & $11.6 \pm 5.01$ & $12.5 \pm 3.85$ & $4.5 \pm 0.96$ & $3.4 \pm 1.33$ & $4.5 \pm 1.99$ & $4.2 \pm 1.63$ & $0.02-0.5^{\mathrm{A}}$ \\
\hline $\mathrm{Cu}$ & $6.0 \pm 2.26$ & $5.8 \pm 2.19$ & $3.4 \pm 1.33$ & $4.8 \pm 1.69$ & $4.5 \pm 1.99$ & $4.2 \pm 1.63$ & $5-30^{A}$ \\
\hline
\end{tabular}

A - Kabata Pendias and Pendias (2001)

B - Market (1992)

$\mathrm{Zn}>\mathrm{Pb}>\mathrm{Cr}>\mathrm{Ni}>\mathrm{Cu}>\mathrm{Co}$. There were no significant differences in metal contents in the studied years 2014 and 2015, and the amounts of analyzed metals were comparable. The highest average contents were found in 2014 in the case of $\mathrm{Zn}(180.9 \pm 138.69)$, while the lowest for Co (4.6 \pm 1.28$)$. By studying the results for bottom sediments in Bug river, it was found that the contents of $\mathrm{Ni}, \mathrm{Co}, \mathrm{Cr}$ and $\mathrm{Cu}$, according to Turekian and Wedephol [1961] were at the geochemical background level, and according to Sokołowska and Bojakowska [1998] as well as Bojakowska [2001] - only $\mathrm{Cu}$ (Table 2). It should be noted that studied sediments from the Bug river are not contaminated [Muller 1981]. Bug is a river that throughout the entire course preserved not only its natural, meandering riverbed, but also slightly transformed valley.

Macrophytes, as a group of organisms that are strongly related to the aquatic environment and sensitive to changes in the ecosystem, are the subject of research of many scientists [Klink et al., 2013, Kumar et al., 2006, Wenzeli Jockwer, 1999, Sukumaran, 2013]. Aquatic plants purify the surface water by means of the accumulation of dissolved metals in their tissues. They are a valuable complement to studies upon bottom sediments [Skorbiłowicz, 2012]. Tests revealed that mean contents of $\mathrm{Cu}$ and $\mathrm{Zn}$ were within the range of natural contents proposed by KabataPendias and Pendias [2001] as well as Markert [1992]. Nevertheless, concentrations of $\mathrm{Pb}, \mathrm{Ni}$, $\mathrm{Co}$, and $\mathrm{Cr}$ in roots, stems, and leaves appeared to be higher than maximum value listed in Table 3. According to Otte and Jakub [2005], deviations from natural contents may indicate plants that can be appropriate for the biological monitoring. Studied metals were accumulated in the following sequences: root $\mathrm{Zn}>\mathrm{Pb}>\mathrm{Cr}>\mathrm{Ni}>\mathrm{Cu}>\mathrm{Co}$, stem $\mathrm{Zn}>\mathrm{Pb}>\mathrm{Ni}>\mathrm{Cu}>\mathrm{Cr}>\mathrm{Co}$, leaf $\mathrm{Zn}>\mathrm{Pb}>\mathrm{Ni}>\mathrm{Cr}>\mathrm{Cu}>\mathrm{Co}$. The highest content in examined plant organs were present in the case of zinc, and the smallest amounts were reported for cobalt. Zinc is an element necessary for the proper functioning of living organisms, but its excess is harmful. It is one of the more mobile metals within the environment and is actively taken up by roots. Elevated concentrations of zinc can be an indicator of industrial pollution in rivers [Caldwell et al. 2007], but the average concentration of $\mathrm{Zn}$ in the present research ranged within the natural content. 
Referring to the distribution of metals within the plant, contents of all metals at each measurement point were the highest in roots, which was confirmed by tests carried out by [Jiao et al., 2014, Klink et al., 2013]. Analyzed metals are accumulated in the order: $\operatorname{root}>$ leaf $>$ stem. Similar patterns of metals distribution in aquatic plant organs were showed by Bonanno, [2013]; Bonanno and Lo Giudice, [2010]; Vymazal et al., [2009]. This means that the metal contents are consistently higher in the roots than in the aboveground parts, although concentrations in leaves and stems are more variable and dependent on a metal [Lyubenova et al, 2013, Sukumaran, 2013]. According to Idaszkin et al. [2014], some metals are accumulated mainly in the root due to the existence of a physiological barrier for transport to the aboveground parts of plant, while other metals may be easily transferred to the stem and leaves.

Generally, it can be indicated that the average metal distribution in tested plants grown in the Bug river and in bottom sediments was as follows: $\mathrm{Pb}, \mathrm{Zn}$, $\mathrm{Co}$ and $\mathrm{Cu}$ sediment $>$ root $>$ leaf $>$ stem. However, in the case of $\mathrm{Ni}$ and $\mathrm{Cr}$, the contents were greater in roots than in sediment (root $>$ sediment $>$ leaf $>$ stem), although differences in the contents were not large. It should be noted that the content of metals in bottom sediments depends on factors such as $\mathrm{pH}$, organic matter content, redox potential, and particle size distribution [Madej, Germ 2009, Rochel et al. 2008]. These factors also affect the metal contents in plants and should be taken into account in future studies.

In order to assess the transfer of metals from sediments to the roots, the bioaccumulation factor was calculated as the ratio of studied metals content in roots to their quantities in bottom sediments (Table 4). The average value of this factor increased in the following sequence: $\mathrm{Ni}>\mathrm{Cr}>\mathrm{Cu}>\mathrm{Pb}>\mathrm{Co}>\mathrm{Zn}$. In the case of $\mathrm{Ni}, \mathrm{Cr}$, and
$\mathrm{Cu}$ in 2014, the bioaccumulation factor was greater than 1, which confirms a remarkable efficiency in these metals uptake from the environment. The bioaccumulation factor (BF) was lower than 1 for $\mathrm{Pb}, \mathrm{Co}$ and $\mathrm{Zn}$, and similar results were found by Wenzeli Jockwer [1999]. They indicated that the transfer of potentially toxic metals from bottom sediments to plant roots was poor. Analyzed translocation factors (TF) provide an information on an internal transport of metals at plants. Studies revealed that translocation factor (TF) for all analyzed metals (except from Co in 2015) was lower than 1 (Table 3), which confirmed the high ability to metal retention in roots [Id et al., 2012].

The results of the conducted analyses of metals in bottom sediments and aquatic plants grown in the Bug river to a large extent depended on the geochemical structure of the catchment. Nevertheless, the metal contents in the sediments is also influenced by the state of the catchment development. Anthropogenic sources of water pollution in the Bug river catchment include wastewater discharged from population centers and industrial plants, surface runoff from farmlands, cities and transport routes. The largest contents of examined metals in bottom sediments and aquatic plants occurred at the measurement point Siemiatycze, which was confirmed by the dendrogram obtained as a result of cluster analysis (Figure 3 ). It presents two main arrangements: the first covers the most contaminated measuring point in Siemiatycze. The fruit processing plants that produce concentrated juices and purees ("O.K. Owocowe Koncentraty"), sewage treatment plant, dairy factory, and companies involved in the metal-sheet industry, are located in Siemiatycze. The second arrangement includes the rest of measurement points, certainly affected by the impacts resulting from agricultural activities, transport, and the influence of the sewage treatment plant located near the measurement points.

Table 4. Transfer factor of metals from roots to the other organs of plans from the Bug river (mean \pm SD).

\begin{tabular}{|c|c|c|c|c|c|c|}
\hline \multirow{2}{*}{ Metal } & \multicolumn{7}{|c|}{ Root/sediment } & \multicolumn{2}{c|}{ Stem/root } & \multicolumn{2}{c|}{ Leaf/root } \\
\cline { 2 - 7 } & 2014 & 2015 & 2014 & 2015 & 2014 & 2015 \\
\hline $\mathrm{Pb}$ & $0.8 \pm 0.39$ & $0.9 \pm 0.15$ & $0.6 \pm 0.16$ & $0.7 \pm 0.13$ & $0.9 \pm 0.12$ & $0.7 \pm 0.18$ \\
\hline $\mathrm{Zn}$ & $0.5 \pm 0.28$ & $0.6 \pm 0.35$ & $0.5 \pm 0.23$ & $0.6 \pm 0.15$ & $0.7 \pm 0.37$ & $0.6 \pm 0.29$ \\
\hline $\mathrm{Ni}$ & $1.8 \pm 0.46$ & $1.1 \pm 0.09$ & $0.5 \pm 0.14$ & $0.8 \pm 0.19$ & $0.7 \pm 0.22$ & $0.8 \pm 0.07$ \\
\hline $\mathrm{Co}$ & $0.8 \pm 0.28$ & $0.8 \pm 0.25$ & $0.5 \pm 0.15$ & $0.7 \pm 0.21$ & $0.8 \pm 0.34$ & $1.0 \pm 0.33$ \\
\hline $\mathrm{Cr}$ & $1.1 \pm 0.41$ & $1.2 \pm 0.28$ & $0.5 \pm 0.16$ & $0.4 \pm 0.14$ & $0.3 \pm 0.09$ & $0.4 \pm 0.21$ \\
\hline $\mathrm{Cu}$ & $1.3 \pm 0.54$ & $0.9 \pm 0.24$ & $0.6 \pm 0.14$ & $0.8 \pm 0.18$ & $0.8 \pm 0.25$ & $0.7 \pm 0.12$ \\
\hline
\end{tabular}


Calculation of the correlation coefficient (Pearson) allowed to define a linear relationship between the analyzed variables. Figures 1 and 2 show graphic interpretations of the correlation coefficient called scatterplots. Scatterplots, besides the line, mark the dashed lines indicating $95 \%$ confidence interval for the line. Analyzes of achieved correlations indicated their statistical significance, which proves their computing correctness. The resulting dependences are linear. They took the form of regression curves described by linear equation, which is essentially based on a mathematical model that can predict the values of analyzed variables. In this work, a series (Figures 1 and 2) mathematical equations (models) was achieved, on basis of which e.g. metal contents in the plant organs based on their contents in bottom sediments, can be predicted. The resulting models belong to the class of simple ones, but giving the possibility to carry out the elementary forecasting of heavy metal contents often subject to a complex translocation within a system: various organs of plants - bottom sediments. The study proved that uptake of investigated metals by plants is highly influenced by their contents in bottom sediments, as confirmed by statistical analysis, especially in the case of $\mathrm{Ni}, \mathrm{Cr}$, and $\mathrm{Cu}$.

\section{CONCLUSIONS}

1. The conducted analysis of metals in bottom sediments has shown that they are not contaminated. Bug is a river that throughout the entire course preserved not only its natural, meandering riverbed, but has also slightly transformed valley.

2. It has been shown that the average metal distribution in the examined plants present in the Bug river and bottom sediments was as follows: $\mathrm{Pb}, \mathrm{Zn}, \mathrm{Co}$, and $\mathrm{Cu}$ sediment $>\operatorname{root}>\mathrm{leaf}>$ stem, and in the case of $\mathrm{Ni}$ and $\mathrm{Cr}$, the contents were greater in roots than in sediments (root $>$ sediment $>$ leaf $>$ stem), although the differences in contents were not large.

3. The study showed that the highest quantities of metals are present in the roots and only a small part of them are transported to the stem and leaves. Transport of metals within plants can also vary depending on their concentrations.
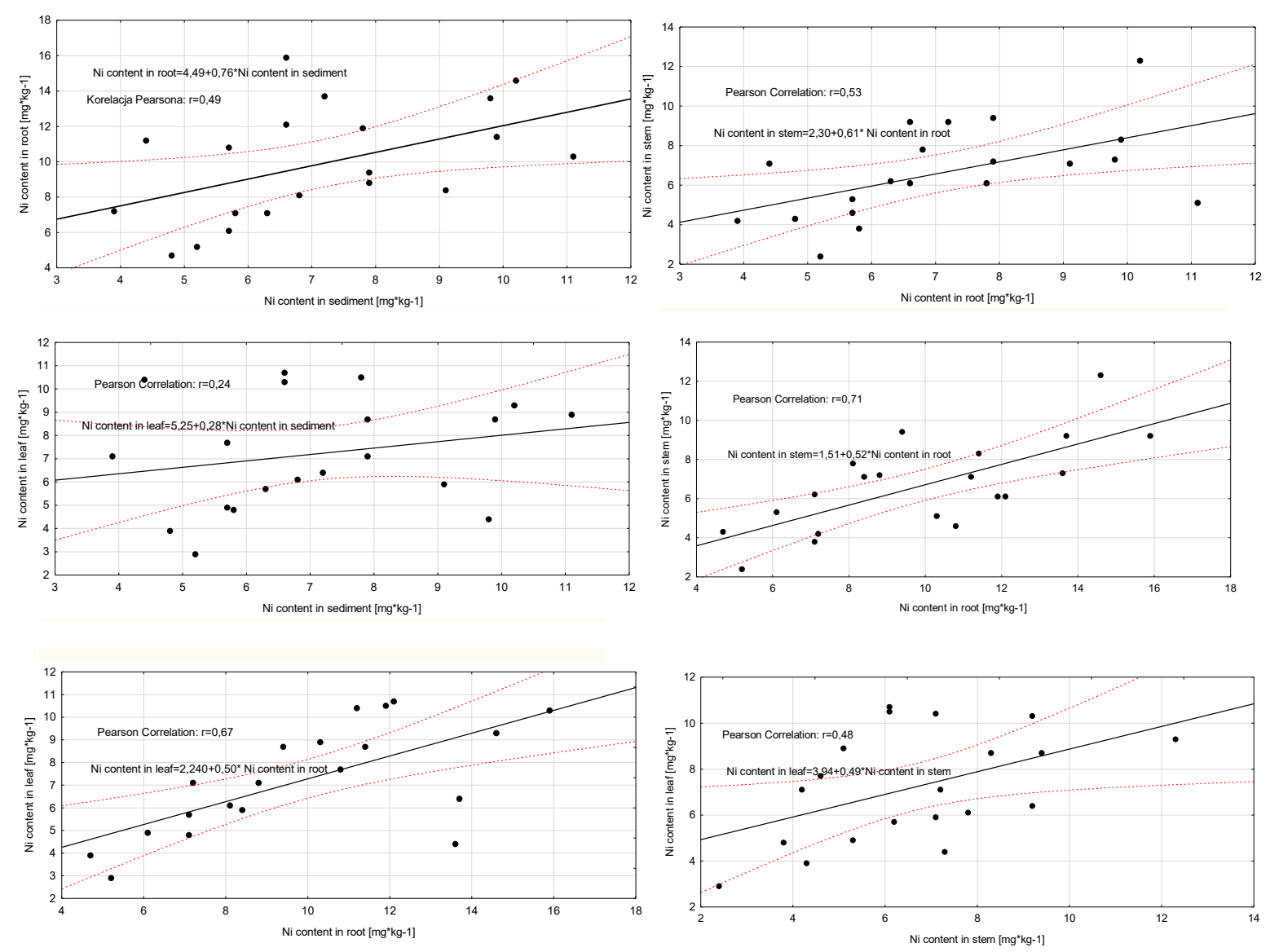

Figure 1. Correlations of Ni contents in bottom sediments and aquatic plants (root, stem, leaf) 

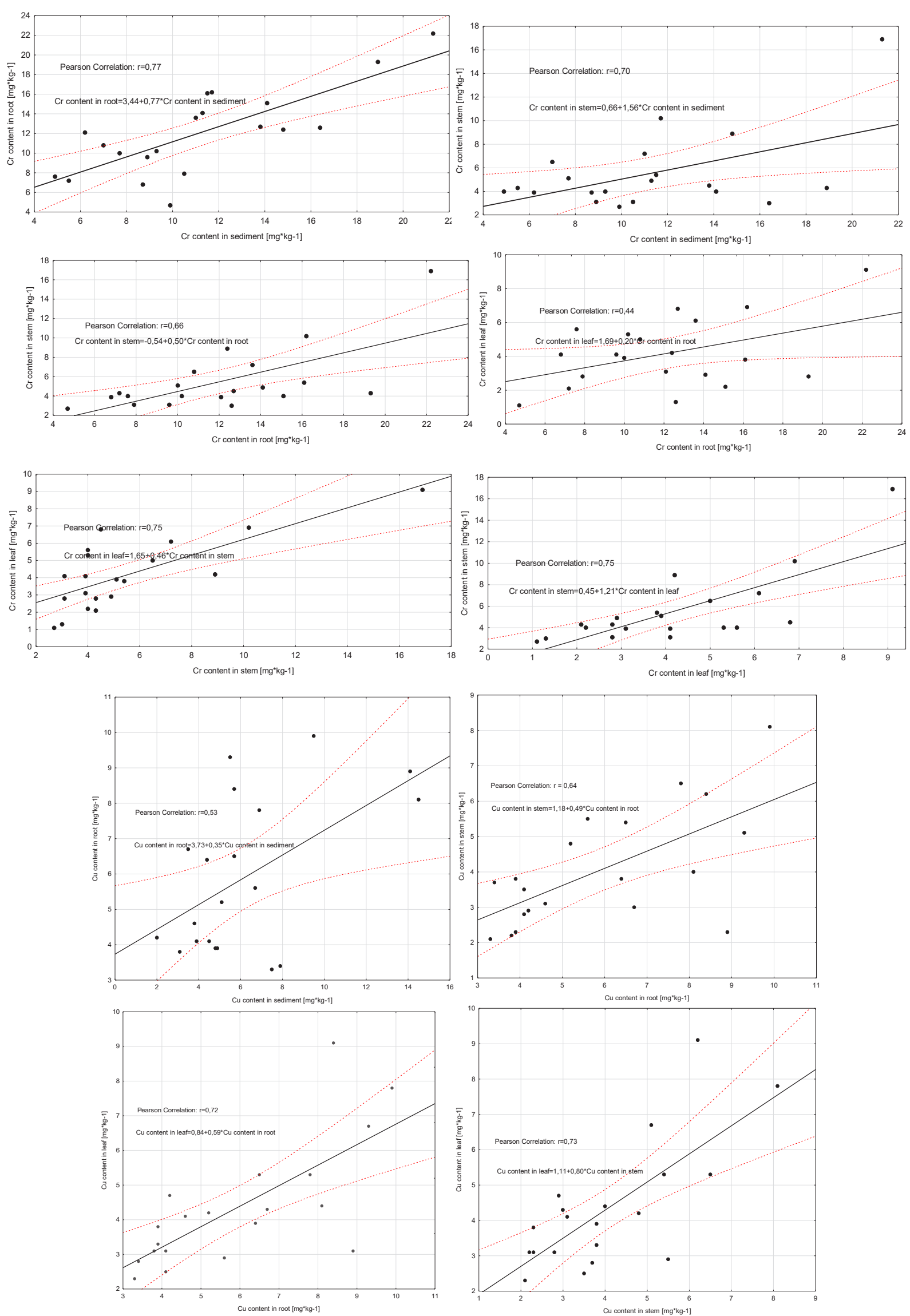

Figure 2. Correlations of $\mathrm{Cu}$ and $\mathrm{Cr}$ contents in bottom sediments and aquatic plants (root, stem, leaf) 


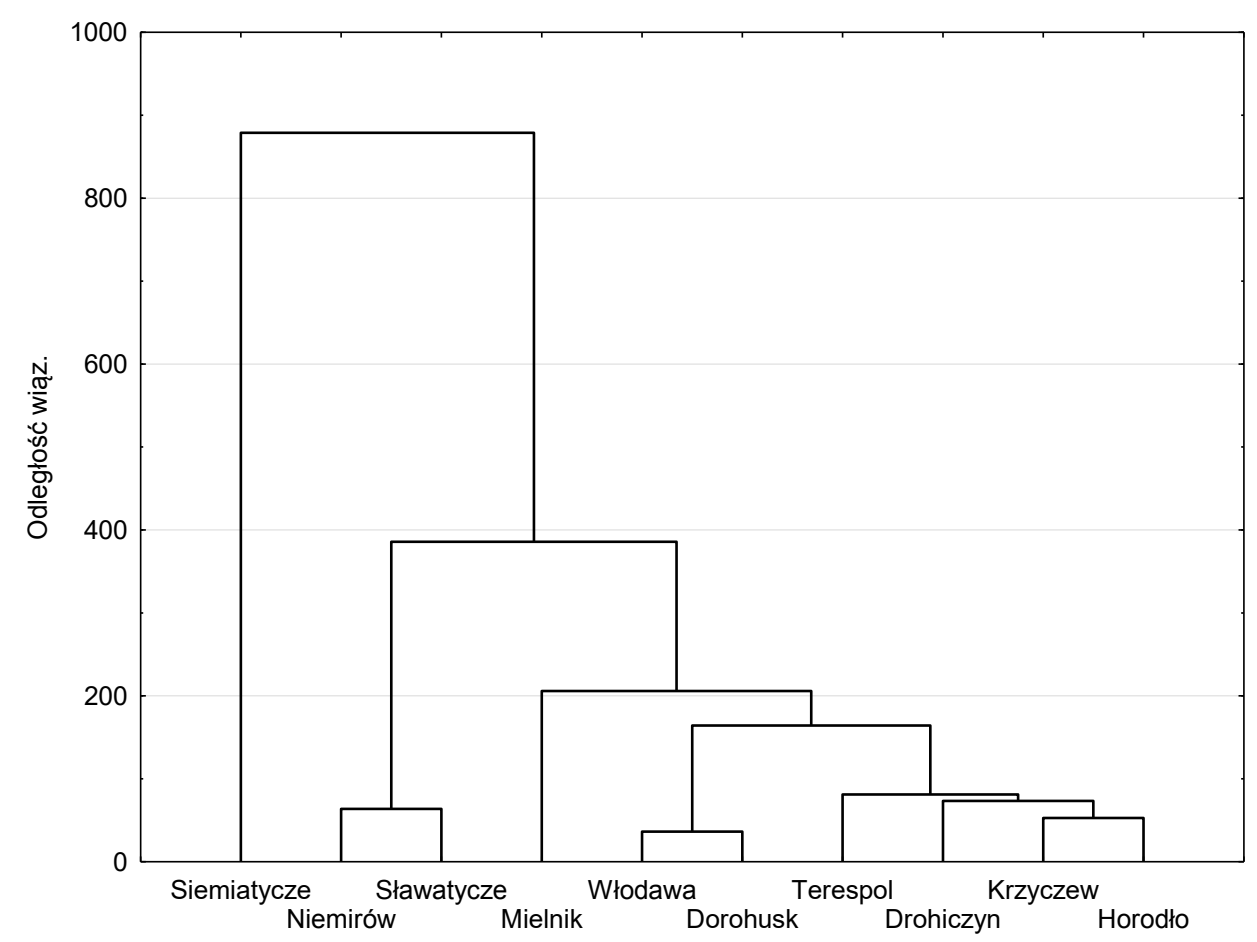

Figure 3. Dendrogram for bottom sediments and aquatic plants of Bug river according to Ward procedure (1963)

4. It was found that for $\mathrm{Ni}, \mathrm{Cr}$ and $\mathrm{Cu}$ in 2014, the bioaccumulation factor was above 1 , which confirms the high efficiency of these metals uptake from the environment as evidenced by statistical analysis. Bioaccumulation factor $(\mathrm{BF})$ was less than a unit for $\mathrm{Pb}, \mathrm{Co}$ and $\mathrm{Zn}$.

5. Studies have shown that translocation factor (TF) for all analyzed metals (excluding Co in 2015) was below 1 , confirming the high ability to retain metals in the root.

6. Aquatic plants are an effective barrier for surface water, accumulating heavy metals in their biomass. Macrophytes are proposed to monitor the river pollution.

7. The content of metals in test aquatic plants and bottom sediments collected from the Bug river depended on the state of its development. The differences in the element contents in studied parts of the aquatic environment depended on the location of the measurement point.

\section{REFERENCES}

1. Barrat-Segretain M.H., 2001. Biomass allocation in macrophytespecies in relation to the disturbance level of their habitat. Freshwat. Biol., 46, 935-945.

2. Bojakowska I. Sokołowska G., 1998. Geochemiczne klasy czystości osadów wodnych. Przegl. Geolog. 46, 1, 49-54.
3. Bojakowska I., 2001. Kryteria oceny zanieczyszczenia osadów wodnych. Przegl. Geolog., 49, 3, 213-218.

4. Bonanno G., 2013. Comparative performance of trace element bioaccumulation and biomonitoring in the plant species Typha domingensis, Phragmites australis and Arundo donax. Ecotoxicol. Environ. Saf. 97, 124-130.

5. Bonanno G., Lo Giudice R., 2010. Heavymetal bioaccumulation by the organs of Phragmites australis (common reed) and their potential use as contamination indicators. Ecol. Indic. 10, 639-645.

6. Dmochowski D., 1995, Analiza możliwości zastosowania specjacji metali ciężkich do oceny zanieczyszczenia wód powierzchniowych na terenach zurbanizowanych, praca doktorska, Politechnika Warszawska, Wydział Inżynierii Środowiska, Warszawa.

7. Dauvalter V., Rognerud S., 2001, Heavy metal pollution in sediments of the Pasvik River drainage, „Chemosphere”, 42, 9-18.

8. Dombrowski A, Glowacki Z, Jakubowski W., Kovalchuka I., Michalczyk Z., Nikiforova M., Szwajgier W., Wojciechowski K., 2002, Korytarz ekologiczny doliny Bugu. Stan-Zagrożenia- Ochrona, Praca zbiorowa, 350.

9. Eid, E.M.,Shaltout, K.H.,El-Sheikh, M.,Asaeda, T., 2012. Seasonal courses of nutrients and heavy metals in water, sediment and above- and belowground Typha domingensis biomass in Lake Burullus (Egypt): perspectives for phytoremediation. 
Flora 207, 783-794.

10. Fediuc E., Erdei L., 2002, Physiological and biochemical aspects of cadmium toxicity and protective mechanisms induced in Phragmites australis and Typha latifolia, J. Plant Physiol., 159, 265-271.

11. Fritioff A., Greger M., 2006, Uptake and distribution of $\mathrm{Zn}, \mathrm{Cu}, \mathrm{Cd}$, and $\mathrm{Pb}$ in an aquatic plant Potamogeton natans, Chemosph., 63, 220-227

12. Gworek B., Kwasowski W., 2001, Wpływ motoryzacji na środowisko, w: Obieg pierwiastków w przyrodzie, red. B. Gworek, A. Mocka, monografia, t. 1, IOŚ, Warszawa, 39-48.

13. Helios-Rybicka E., 1991, Akumulacja i mobilizacja metali ciężkich w osadach środowiska wodnego: osady datowane jako wskaźnik chronologiczny, Mat. Konf. „Geologiczne aspekty ochrony środowiska”, Kraków, 18-23.

14. Helios-Rybicka E., Wardas M., Adamiec E., Strzebińska M., 2001. Ocena zanieczyszczenia rzeki Odry I Wisły - przeszłość i teraźniejszość, Geol., 27, 659-671.

15. Idaszkin, Y.L., Bouza, P.J., Marinho, C.H., Gil, M.N., 2014. Trace metal concentrations in Spartina densiflora and associated soil from a Patagonian salt marsh. Mar. Pollut. Bull. 89, 444-450.

16. Jiao, M., Li, X., Liu, J.Y., Tian, Y.Q., Huang, Y., Gao, C.M., Chen, X.J., 2014. Study of absorption of heavy metals $(\mathrm{Pb}, \mathrm{Cu})$ in Phragmites australis in Lingang New City. Appl. Mech. Mater. 692, 3-7.

17. Kabata-Pendias A., Pendias H., 1999, Biogeochemia pierwiastków śladowych, PWN, Warszawa.

18. Kabata-Pendias, A., Pendias, H., 2001. Trace Elements in Soils and Plants, Third edition. CRC Press, Boca Raton, London, New York, Washington, D.C.

19. Karczewska A., 2002, Metale ciężkie w glebach zanieczyszczonych emisjami hut miedzi - formy i rozpuszczalność, Instytut Gleboznawstwa i Ochrony Środowiska Rolniczego, Wrocław.

20. Klink, A., Macioł, A., Wisłocka, M., Krawczyk, J., 2013. Metal accumulation and distribution in the organs of Typha latifolia L. (cattail) and their potential use in bioindication. Limnol.-Ecol. Manage. Inland Waters 43, 164-168.

21. Linnik P. M., Zubenko I. B., 2000, Role of bottom sediments in the secondary pollution of aquatic environments by heavy-metal compounds lakes and reservoirs, Res. Manage., 5, 11-21.

22. Lis J., Pasieczna A., 1995, Atlas geochemiczny Polski w skali 1: 2,500,000, Państw. Inst. Geol., Warszawa.

23. Lyubenova, L., Pongrac, P., Vogel-Mikuš, K., Mezek, G.K., Vavpetic`, P., Grlj, N., Regvar, M., Peli- con, P., Schroder, P., 2013. The fate of arsenic, cadmium and lead in Typha latifolia: A case study on the applicability of micro-PIXE in plant ionomics. J. Hazard. Mater. 248, 371-378.

24. Markert B., 1992, Presence and significance of naturally occurring chemical elements of the periodic system in the plant organism and consequences for future investigations on inorganic environmental chemistry in ecosystems, Veget., 103, 1-30.

25. Mazej Z., Germ M., 2009, Trace element accumulation and distribution in four aquatic macrophytes, „Chemosph.”, 74, 642-647.

26. Mazur T., Sądej W., Mazur Z., Wojtas A., 2002, Produkcyjno-ekologiczne skutki stosowania gnojowicy. Acta Agroph., 70, 265-269.

27. Mielke H.W., Laidlaw M.A., Gonzales C., 2010. Lead $(\mathrm{Pb})$ legacy from vehicle traffic in eight California urbanized areas: continuing influence of lead dust on children's health. Sci. Total Environ. 408, 3965-3975.

28. Otte M.L., Jacob D.L., 2005. Chemical fingerprinting of plants from contrasting wetlands-salt marsh, geothermal and mining impacted. Phyton 45, 303-316.

29. Skorbiłowicz E., Bojakowska J., 2006, Influence of sewage disposal on zinc contents in waters and bottom sediments of selected rivers in Podlasie region, „Pol. J. Environ. Stud.”, 15, 5D, 695-699.

30. Sousa A.I., Caçador I., Lillebø A.I., Pardal M.A., 2008, Heavy metal accumulation in Halimione portulacoides: Intra- and extra-cellular metal binding sites, "Chemosph.", 70, 850-857.

31. Sukumaran D., 2013. Phytoremediation of heavy metals from industrial effluent using constructed wetland technology. Appl. Ecol. Environ. Sci. 1, 92-97.

32. Turekian K.K., Wedephol K.H., 1961, Distribution of the Elements in Some Mayor Units of the Earth s Crust, „Bull. Geol. Soc. Am.”, 72, 175-184

33. Vymazal J., Kropfelova L., Švehla J., Chrastny' V., Štichova J., 2009. Trace elements in Phragmites australis growing in constructed wetlands for treatment of municipal wastewater. Ecol. Eng. 35, 303-309.

34. Wenzel W.W., Jockwer F., 1999. Accumulation of heavy metals in plants grow on mineralized soils in the Austrian Alps. Environ. Pollut. 104, 145-155.

35. Yang Y., He Z., Lin Y., Philips E.J., Stofella P.J., Powell C.A., 2008, Temporal and spatial variations of Copper, Cadmium, Lead, and zinc in Ten mile Creek in south Florida, USA. Wat. Environ. Res., $81,1,40-50$. 